\title{
Development Of Submitting Module Handware And Handmade Maintenance Competency To Increase Creativity And Student Learning Results In Vocational High School
}

\author{
Rizky Yulianingrum Pradani, Luthfiyah Nurlaela, Wahono Widodo \\ Pendidikan Teknologi dan Kejuruan Pascasarjana, Universitas Negeri Surabaya \\ Surabaya, Indonesia \\ rizki.yulia.ft@um.ac.id
}

\begin{abstract}
The purpose of this study was to determine: the feasibility of modules developed to support learning with a model Problem Based Learning, the activities of teacher and students in teaching and learning activities using the module Manicure with problem based learning, the difference creativity students who use the module with a model problem based learning with sudents who do not use the module, differences in student learning outcomes using the module with a model problem based learning and student who do not use the module, students response to the application of the learning modules in manicure. Type of research is a continued development of the experimental research. As for advice-advoce from researchers and reproduced images, further research is needed to more observers in the study as small as possible so that the activity of the students in expressing the response of the media developed note, type of research needs to be done because of the need on departement of family wefare education learning modules to very much, not only on the material manicure, for futher research training should choose the currency in wich there are theories that can be practiced or visualized.
\end{abstract}

Keywords---Module Learning, Creativity; Learning outcomes; Competencies Sub Manicure

\section{INTRODUCTION}

In an ever-changing society, ideally education is not only oriented toward the past and the masses now. But it is a process that anticipates and talks about the future. Education as well as one part of social aspects that have a double position that is strategic and critical position. The strategic position because education is able to live consistently overcome the threats and challenges of the future, which means education must be fiuturistic or future-oriented.

Learning is a complex process that occurs in every person throughout his life. Learning process occurs because of the interaction between a person with his environment. Therefore, learning can happen anytime and anywhere. One sign that a person has learned is a behavioral change in the person caused by changes in the level of knowledge (cognitive), attitude (affective) and skills (psychomotor).
Permendiknas no. 23 year 2006 about Graduate Competency Standards (SKL) SMK / MA states that build and apply information and knowledge logically, critically, creatively and innovatively and show the ability of logical thinking, critical, creative and innovative in decision making. Through the educational effort is expected to the quality of students who are smart, creative and innovative can be realized.

Creativity reflects a divegrenous thinker who is capable of providing a variety of alternative answers. Creativity can be used to predict learning success. But actually everyone is creative. To get it needs training and guidance from parents and teachers. Changes to improvement and refinement of learning and improvement in education are manifested by innovation or change activities. The changes or innovations are devoted to the learner, educational goals, lesson materials, educational media, educational facilities, teaching methods, evaluation, teaching and learning situations.

Vocational High School (SMK) as one of the formal educational institutions that have the vision and mission to educate the life of the nation and also aims to provide knowledge and skills for learners. Vocational High School (SMK) is one form of a formal education unit that conducts vocational education at secondary level as a continuation of junior high school, MTs, or other equivalent or advanced learning achievement that is equal / equivalent to SMP / MTs.

The knowledge and skills that are the areas of competency in SMK especially the SMK Tourism is the field of cosmetology, the field of culinary and the field of fashion. In the field of cosmetology is expected that students are able and skilled in all areas related to the tightness. One of the areas that must be mastered is the areas of treatment include: body care, facial care, hair care, foot care, hand care and nail makeup (Manicure).

Selection of one of the teaching methods will influence the appropriate type of instructional media. It can be said that the main function of learning media is as a teaching tool that also influence the climate, condition and learning environment that is arranged and created by the teacher, so that will influence the success of learning. Most teachers are incapable 
of conducting interesting and enjoyable learning. This situation is due to one of them due to lack of innovative materials developed. Educators generally only provide monotonous teaching materials, which are already available and live in use. So, in the end learners will feel bored follow the learning process, so that the learning process becomes ineffective and efficient [1].

According to Surahman (2011), said that the module is the unit of the smallest learning program that can be learned by the learners individually (self instructional); After the participants complete one unit in the module, then the participants can step forward and learn the next module unit.

Based on the above description, the researcher focuses this research on the development of learning tools that will be used by students in teaching and learning activities. This research entitled: Development of Sub Module of Hand Caring Competence and Nail Make Up to Improve Creativity and Student Results of SMK.

\section{METHOD}

\section{A. Types of research}

This research is a research development continued experimental research. Research development in question is this research was conducted to produce learning modules on hand and nail care materials in SMK. Learning tool that will be developed is learning device Hand Care and Nail Make Up (Manicure) oriented to model of learning based on problem. The device includes the Student Module and the Teacher Module.

In this study, the population is all students of class $\mathrm{X}$ SMK Negeri 1 Batu, amounting to 30 students, all students of class X Beauty Beauty Skin 1 and Class X Beauty Skin 2 SMK Negeri 2 Boyolangu Tulungagung. The sample is part of the number and characteristics possessed by the population (Sugiyono, 2011: 62). Samples taken in this study is class X Beauty Beauty Skin with the number of 15 students.

\section{B. Design of Research Device Development}

The design of this research tool development adapted the development of $\mathrm{R} \& \mathrm{D}$ model device (Research and Development).

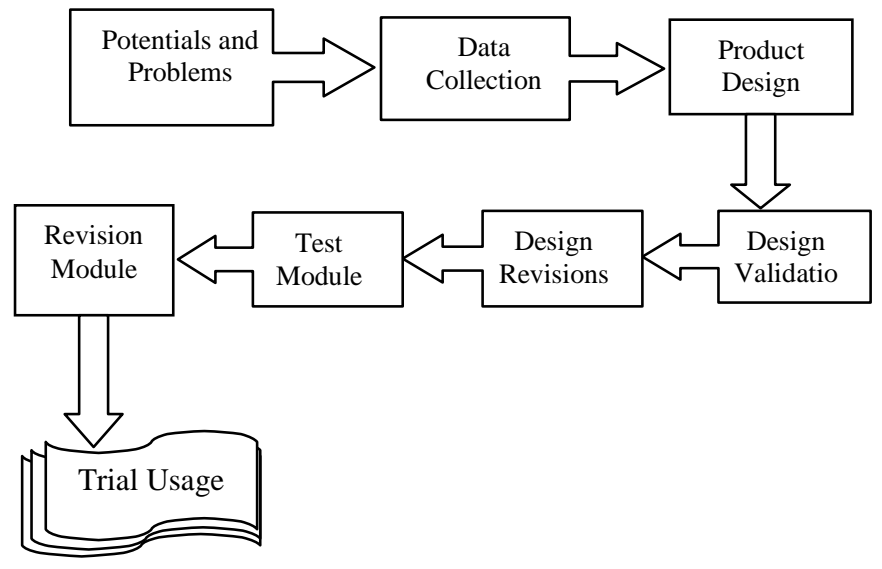

Fig 1. Model of Learning Device Development R \& D[2]
The development of this model device consists of four stages, namely potential and problem stage, data collection, product design, design validation, design revision, module test, module revision, trial usage, product revision and mass production. Because the results of this research are not disseminated on Other schools (other than research sites) then haya is used until trial use.

The data collected in this study used Pretest-Posttest Control Group Designs research design, as a study with a comparison group, where the module application was then applied to gain learning outcomes.

\begin{tabular}{|llll|}
\hline $\mathbf{E}_{1}$ & $\mathbf{O}^{\prime}{ }_{1}$ & $\mathbf{x}$ & $\mathbf{O}_{1}$ \\
$\mathrm{~K}$ & $\mathbf{O}^{\prime}{ }_{2}$ & - & $\mathbf{O}_{2}$ \\
\hline
\end{tabular}

Fig 2. Design of research

\section{Data Collection Technique}

The type of method chosen and used in terms of data collection, must be in accordance with the nature and characteristics of the research conducted. The data collection techniques used in this research are: a) observation; b) test Student learning outcomes; c) questionnaire.

Insrumen that have been use in this research are: 1) sheet validation; 2) questionnaire Teacher and Student Activity; 3) questionnaire of Student Responses; 4) observation Sheet of Learning Management; 5) student Creativity Test; 6) test Student Learning Outcomes (Written Test, Performance Test).

\section{Data Analysis Technique}

The data analyzed are observation data, learning result and response questionnaire data:

\section{- Management of Learning}

The scale of the learning management rating category is based on the Linkert scale of each observed aspect: Rating 1 (less good), Rating 2 (good enough), Assessment 3 (good), Rating 4 (very good). The ability of teachers during the teaching and learning process is seen from the average of each aspect of teaching and learning activities which is calculated by the formula:

\section{$\frac{\text { Jumlah skor yang diperolah }}{\text { Jumlah skor maksimal }} \times 100 \%$}

- Data Analysis of The Frequency of Student Activity

Data obtained from student activity frequency sheets were analyzed quantitatively by using the formula:

$$
\mathrm{F}=\frac{A}{B} x 100 \%
$$

- Analysis of Test Data 
Data of learning result test show mastery learn student by using multimedia. The evaluation test data obtained were analyzed by:

$$
\text { SKOR }=\frac{B}{N} x 100 \%
$$

Test score data can be known directly at the time students do evaluation questions using multimedia. The learning completeness data are classically analyzed by using the following formula:

$$
\text { SKOR }=\frac{\sum B \times \sum F}{\sum N \times \sum F} \times 100 \%
$$

\section{- Students Response Questionnaire Analysis}

Questionnaire responses of students analyzed descriptively quantitatively calculated by percentage based on Likert:

$$
K=\frac{F}{N} x 100 \%
$$

As for the overall count, use the formula [4]:

$$
P=\frac{\sum K x \sum N}{\sum F \times \sum N} \times 100 \%
$$

The result of the percentage calculation from the student questionnaire is interpreted into the criteria that can be seen in table I below :

\section{TABLE I. CRITERIA PERCENTAGE OF STUDENT RESPONSE TO MULTIMEDIA BASED MEDIA LEARNING [4]}

\begin{tabular}{|c|c|}
\hline Percentage & Criteria \\
\hline $0 \%-20 \%$ & Very Bad \\
\hline $21 \%-40 \%$ & Not Good \\
\hline $41 \%-60 \%$ & Pretty good \\
\hline $61 \%-80 \%$ & Good \\
\hline $81 \%-100 \%$ & Very Good \\
\hline
\end{tabular}

Based on these criteria, multimedia in this study is said to be effective if the percentage $\geq 61 \%$

\section{RESULTS}

Based on the results of the research the next step is to discuss the results of research to reach the conclusion of research in accordance with the formulation of problems that have been established at the beginning of the study. Discussion of this research as follows:

\section{A. Discussion of Learning Management Results}

Teaching and learning process using learning module of hand care and nail care (Manicure), it is known that the average value of observer is 3,96 . If calculated by percentage, then the percentage of learning management in SMKN 1 Batu 93,33\% while in SMKN 2 Boyolangu equal to 92,5\%. These results indicate that the learning management is categorized very well. But in SMK Negeri 1 Batu there are two components that get a value of 10 while in SMK Negeri 2 Boyolangu there is one component that gets a value of 10 .

\section{- $\quad$ Student Activity Frequency Discussion}

Data of observation result of student activity obtained by observing student activity during teaching learning process. While the learning is done in the practice room with a capacity of 60 students. It aims to know the activities of students such as paying attention to teacher explanations, able to formulate hypotheses, plan planning, experiment, create works, display works and so forth.

Based on the result of the learning module test, it can be concluded that the students listen to the explanation (guidance) \pm as much as $7.1 \% \mathrm{~s} / \mathrm{d} 14.3 \%$, students formulate hypothesis \pm as much as $6.7 \% \mathrm{~s} / \mathrm{d} 14.3 \%$, students can plan \pm As much as $6.7 \%$ to $15.4 \%$, students can experiment \pm as much as $6.7 \%$ to $15.4 \%$, students can make works \pm as much as $28.6 \%$ to $50.0 \%$, students Can display the works \pm as much as $6.7 \%$ to $7.1 \%$, students focus on the module being read \pm as much as $7.1 \% \mathrm{~s} / \mathrm{d} 21.4 \%$, students actively answer the teacher questions during the learning process lasted $\pm 6,7 \% \mathrm{~s}$ / d $7.1 \%$, students actively inquire during teaching and learning process $\pm 7.1 \% \mathrm{~s} / \mathrm{d} 7.7 \%$, while students perform relevant activities such as play HP, joke as much as $0 \%$. So that the frequency of student activity in the application of learning modules hand and nail care materials (Manicure) with 99\% results. Percentage is if transformed with the conversion value of student activity is very good.

The data shows that during the learning process the students are actively involved so that the irrelevant activity only appears $0 \%$. The data also shows that the highest activity of the students $(35.0 \%$ to $50.0 \%$ ) is to make the work. This means learning by using the learning module has been optimally implemented.

- Results Pretest Students Experiment Class and Control Class

Pretest result data conducted at the beginning of the meeting between the experimental class and control class to know the level of understanding of students before the learning process takes place, so the teacher will know the student's initial understanding of the material that has been delivered at the previous meeting. The pretest result between the experimental class and the control class in Table I indicates that the difference between the classes is not the same. This means the student's initial conditions between the experiment class and the control class are the same. This is because the level of understanding siswaterhadap material at the previous meeting has not been maximized. Not maximal understanding of student caused by less effective and efficient learning like, teacher only explain matter while student just sit listening then record and do matter. This can be seen in the diagram below: 


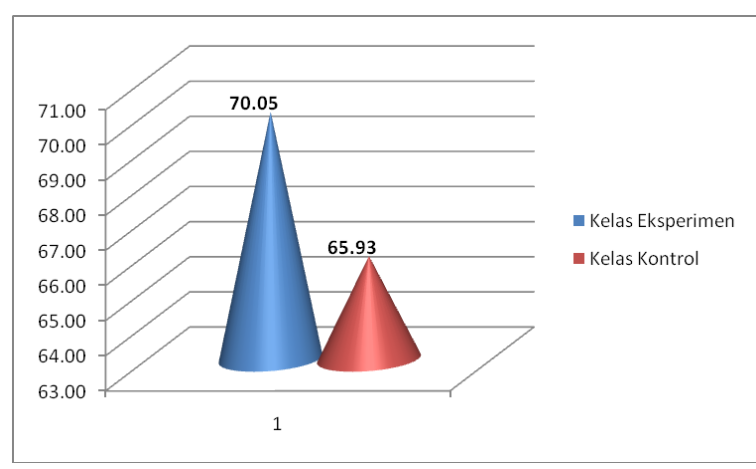

Fig 3. The result of eksperimen and control class Pre-test

\section{- Student Learning Outcomes}

The implementation of Problem Based Learning based module is done at SMK Negeri 1 Batu on Tuesday $05-26$ March 2013 and SMK Negeri 2 Boyolangu Tulungagung on Wednesday, 06 - 27 March 2013. The number of students involved in the application of learning based module Based on the Problem is 60 students.

The data entered is the result of the value of the written test. The data that shows the mastery of student learning when implementing learning by using Problem Based Learning module. From the results of written tests show that the number of individual students mastery in implementing learning by using learning-based learning based on the Problem has been achieved.

This happens because of the effective teaching and learning process between teachers and students is helped by the learning module that facilitates students' understanding on the learning of hand and nail care (Manicure) practice.

Student learning outcomes are increasing because the learning steps based on the problem go well and students follow the steps. At the time of working in groups there are no outstanding students or students who just keep silent. All students in one group express ideas and solve problems.

a. Results of Cognitive Learning

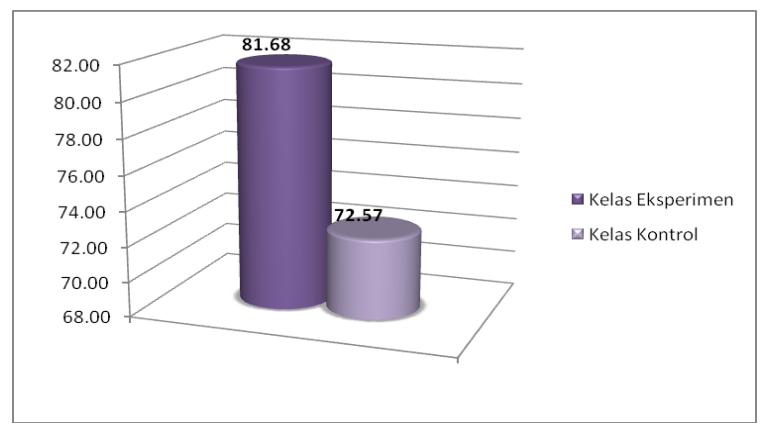

Fig 4. The Result of Postest

In the diagram above shows that the cognitive aspect learning outcomes between the experimental class and the control class looks no difference. The experimental class is $81.68 \%$ higher than in the pretest value that still has not reached the minimum mastery. This is because at the time of pretest the students as a whole have not understood the material described by the teacher. After applied learning by using module, students become more familiar with the material given, seen in posttest value reaching completeness learn as much 58 student from 60 student. The number is increased from the total number of students at the time of the whole pretest (30 students) has not reached the completeness of learning, so that the treatment class is increased after applied learning by using the module.

In the control class it is seen that the posttest value is $70 \%$. The percentage is quite good compared to the time of pretest, so it has reached classical mastery. Improvement in the control class during pretest and posttest is not very high because when given pretest only some students who have understood given the material while for posttest many students who understand the material after the teacher explain / explain all the material by using the lessons often applied in the school.

The above learning results indicate that the learning used in the treatment class is very effective, seen from the level of achievement of learning objectives reached $81.68 \%$ expressed "Completed" in a classical, because the completeness of individual exceeds $80 \%$ after the students follow the learning by using the module on the standard competence Hand care and nail dressing. As for the control class reached $72.57 \%$ and not yet declared "Completed" in classical.

\section{b. Psychomotor Learning Outcomes}

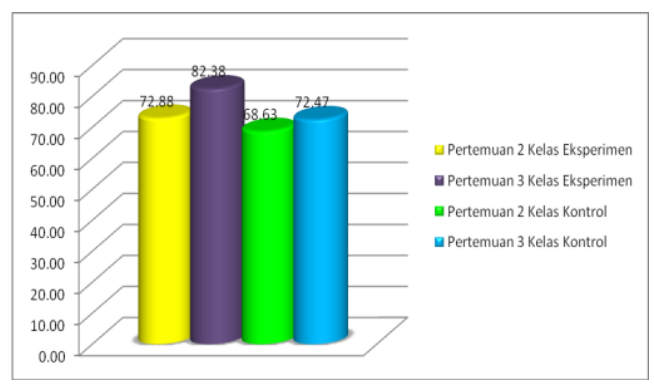

Fig 5. The Result of Psychomotor

The above diagram shows that the learning outcomes of the psychomotor aspects between the experimental class and control class at meeting 2 look different and increase in the meeting 3. The experiment class grade at meeting 2 is $72.88 \%$ while the control class is $68.63 \%$ and at the 3rd meeting Equal to $82,38 \%$ while control class equal to $72,47 \%$. It is seen that there is an increase of student skill to the material learned after applying the learning by using module. The experimental class is stated to reach the completeness classically because it exceeds $80 \%$ at meeting 3 while for the control class is still not declared complete because the completeness of classical completeness is less than $80 \%$. Student learning outcomes with students by using learning modules on the standard of hand and nail care is said to be effective, seen from the classical completeness level at meeting 3 reached $82.38 \%$ after following the learning. 


\section{1) Results of Student Creativity Test}

The data entered is the result of the value of creativity test. The data shows the students' understanding of the learning process by using the Problem Based Learning module. From the results of creativity tests showed that the number of individual students mastery in implementing learning by using learning-based learning based on the Problem has been achieved. Data on student creativity test results that are measured / assessed from tests performed prior to psychomotor testing. Data on student creativity test results that are measured / assessed from tests performed prior to psychomotor testing. Student creativity test data are 2 students from 60 students who get the highest score is 16 and the lowest one student with value 9 .

\section{2) Discussion of Student's Response to Learning Module}

Furthermore, the valid learning module is applied to 60 students. The goal is to find out the responses, responses, and interest of students on learning modules that have been developed. The result data of the students' responses shows that in the experimental class of $98 \%$ in the question items using the learning module is new and by using this model, it is more active in learning. It shows by using the learning module to make the students more active in the learning process and students feel with the new learning for them and can increase their activities and learning outcomes. From the above description it can be concluded that the developed learning module is very well used as a learning module with an overall percentage of $98 \%$ in the experimental class.

From the results of the discussion is the implementation of learning by using learning modules that: $100 \%$ student activity frequency is categorized very well, the learning management of $99 \%$ is categorized very well, student responses to learning modules of $98 \%$ in the experimental class is categorized very well, and student learning outcomes mastery Individual and classical completeness have been achieved both cognitive and psychomotor tests. Based on these data, learning by using learning module in Class $\mathrm{X}$ Beauty Beauty at SMK Negeri 1 Batu and SMK Negeri 2 Boyolangu very good and achieve optimal result.

\section{B. Discussion of Research Results}

\section{- Learning Media}

Learning devices produced in this study is a learning tool that is oriented to the learning model based on the problem. The resulting tools are Learning Module, Lesson Plan, Student Activity Sheet (LKS), Rating Sheet, and Test of Learning Outcomes.

This developed device has been through expert validation process. Based on the validation results, this learning tool is considered good and can be used for research. Furthermore, the device used by researchers to implement learning in the classroom.

The device has been revised by experts and tested in trial 1. Implementation of the second pilot activity was held in
SMK Negeri 1 Batu from 05 to 26 March 2013 and in SMK Negeri 2 Boyolangu from 06 to 27 March 2013.

\section{- Observation of Student Activity in KBM}

According to Lilik Majidatul Zahro's research, there is an increase in student activity at each meeting, which is at meeting I as much as $81.90 \%$, the second meeting is increasing by $95.40 \%$, while the third increase is $98.60 \%$. The increase occurs because the students are getting ready to receive the material so that students can carry out the learning activities using the module well.

Based on the observation data of student activity in Table 1.3 , it is found that the highest frequency of activity done by the students in the learning is making the work. Activity making works becomes dominant activity, it shows in learning the students have willingness to apply what da in module and that have been planned. From the results of data analysis above, it can be said that learning by using the module can make students have the will to practice what is in the module.

- Student's Response to Device and Implementation of Learning

Because it can assist in the process of understanding the material hand care and nail makeup. The student's happy response to the material being learned is supported by the availability of modules for them. Most of them responded with happy module availability and considered it as a novelty because so far they only get hand out. They also enjoy learning strategies that are taught to them, especially problem solving. They love to follow investigation activities and discover new things in learning.

The result data of student response in the diagram above shows that in experiment class of $98 \%$ is in question item by using learning module is new and by using model like this, more active in learning. It shows by using the learning module to make the students more active in the learning process and students feel with the new learning for them and can increase their activities and learning outcomes. From the above description can be concluded that the learning module developed very well is used as a learning module with the overall percentage reaches $98 \%$.

\section{Complete Test Results Student Learning}

- Results of Cognitive Learning

Based on data implementation of learning by using learning module. Complete data analysis of cognitive learning test shows that there is an increase of pretest value because students as a whole do not understand the material described by the teacher. Furthermore, the students' learning mastery measured by KKM shows that individually all students have completed the study with a value above 70 . The completeness of individual learning shows that students are classically complete learning. This result corresponds to the results in the pilot test I where all students complete both individual and classical learning. When compared with the data of the preliminary test results overall student learning outcomes have increased. Based on it can be said that the application of learning by using the module can improve student learning outcomes. 


\section{- Completion of Psychomotor Learning Tests}

Based on data on the data obtained differences and increased in the meeting 3. It appears that there is an increase in student skills to the material learned after applying the learning by using the module. Based on the criteria of mastery learning, the students have been completely studied but individually there are one to three students who are not complete at the meeting 2 . The ability of these three students in completing psychomotor tests is still low, this is partly due to lack of understanding of students and lack of teacher guidance During the learning process individually.

\section{- Results of Student Creativity Test}

The data entered is the result of the value of creativity test. The data shows the students' understanding of the learning process by using the Problem Based Learning module. From the results of creativity tests showed that the number of individual students mastery in implementing learning by using learning-based learning based on the Problem has been achieved.

Data on student creativity test results that are measured / assessed from tests performed prior to psychomotor testing. Student creativity test data in experiment class there are 2 students from 60 students who get the highest score is 16 and the lowest one student with value 9 .

\section{CONCLUSION}

Based on the results of analysis and research on the development of sub modules hand care and nail care to improve creativity and student learning outcomes in the SMK can be concluded several points. From the observation using the learning management module and Makeup Nails Hand Care (Manicure), it is known that the average value of 3.96 if the observer is calculated by the percentage in SMK Negeri 1 Batu amounted to $93.33 \%$ and in SMK 2 Boyolangu by 92 , $5 \%$ so it can be categorized very well. But in SMK Negeri 1 Batu there are two components that get a value of 10 and in SMK Negeri 2 Boyolangu there is one component that gets a value of 10 . Based on the results of research that the activity is often done by students is making the work as much as $35.0 \% \mathrm{~s}$ / d $50.0 \%$, while the activity is rarely done by students is doing irrelevant activities such as: play HP etc $0 \%$. In the experimental class the individual completeness reached $81.68 \%$ and the control class reached $72.57 \%$. Based on the individual mastery of the classical completeness experimental class has been achieved, while the classical control of classical completeness is still not achieved. While the students who have achieved the completeness of individual performance tests exceeds $80 \%$ at meeting 3 while for the control class is still not declared complete because the mastery of classical mastery less than $80 \%$. Thus classical completeness has been achieved. Data on student creativity test results that are measured/assessed from tests performed prior to psychomotor testing. Student creativity test data are 2 students from 60 students who get the highest score is 16 and the lowest one student with value 9 . From the result of the student's response after the whole test, it can be concluded that the module is very well used in the learning of hand and nail care materials (Manicure) with the percentage of all these aspects mean the students give very positive response to the experimental class of $98 \%$.

\section{REFERENCES}

[1] Prastowo, Andi. 2011. Panduan Kreatif Membuat Bahan Ajar Inovatif. Jogjakarta: Diva Press.

[2] Sugiyono. Prof. DR. 2011. Statistic Untuk Penelitian. Bandung: CV. ALfabeta.

[3] Arikunto, Suharsimi. 2006. Prosedur Penelitian Suatu Pendekatan Praktik. Jakarta : PT Rineka Cipta

[4] Riduwan, Drs. 2009. Skala Pengukuran Variabel - Variabel Penelitian. Bandung : Alfabeta

[5] Arikunto, Suharsimi. 1991. Dasar-Dasar Evaluasi Pendidikan. Jakarta : Bumi Aksara

[6] Biologipedia. 2011. Uji Normalitas Gain (Online). (http://biologipedia.blogspot.com/2011./01/uji-normalitas-gain.html tanggal 02 Maret 2013)

[7] Darmawan. 2000. Penggunaan Pembelajaran Berbasis Masalah Dalam Meningkatkan Kemampuan Berpikir Kritis Siswa Pada Pembelajaran IPS di MI Darrusaadah Pandeglang (Online). (http://jurnal.upi.edu/penelitian-pendidikan/view/462/penggunaanpembelajaran-berbasis-masalah-dalam-meningkatkan-kemampuanberpikir-kritis-siswa-pada-pembelajaran-ips-di-mi-darrusaadahpandeglang.html tanggal 10 Juni 2012).

[8] Depdiknas. 1995/1996. Perawatan Tangan, Kaki dan Rias Kuku. Jakarta.

[9] Hamalik, Oemar. 1990. Pendekatan Baru Strategi Belajar mengajar Berdasarkan CBSA. Bandung : Sinar Baru Bandung

[10] Hayardin. 2012. Pengertian Belajar. (http://hayardinblog.blogspot.com/2012/03/artikel-pendidikan-pengertianbelajar.html\#ixzz20CHro3Ue tanggal 01 Juni 2012).

[11] Hasibuan, Moedjiono. 1986. Proses Belajar-Mengajar. Bandung : Remadja Karya CV

[12] Hutabarat, E.P. 1998. Cara Belajar. Jakarta : BPK Gunung Mulia.

[13] Juliantine, Tite. 2010. Jurnal Pengembangan Kreativitas Siswa Melalui Implement ASI Model Pembelajaran Inquiri. (http://file.upi.edu/Direktori/FPOK/JUR._PEND._OLAHRAGA/19680 7071992032-

TITE_JULIANTINE/10._JURNAL_PENGEMBANGAN_KREATIV ITAS_SISWA_MELALUI_IMPLEMENTASI_MODEL_PEMBELAJ ARAN_INKUIRIx.pdf tanggal 02 Juli 2012)

[14] Karakhati, Nathalia. 2002. 10 Teknik \& 20 Kreasi Nail Extension For Nail Art Lovers. Jakarta: PT. Gramedia Pustaka Utama

[15] Krisnayanti, Desy Risna. 2012. "Penerapan Pembelajaran Langsung Pada Kompetensi membuat Sarung Bantal Kursi Dengan Hiasan Anyaman Pita Satin Siswa Kelas VIII F Di SMP Negeri 12 Madiun”. Skripsi tidak diterbitkan. Surabaya : FT UNESA

[16] Kurniawati, Eva. 2007. "Pengembangan Modul Fisika SMK Tentang Usaha, Energi dan Daya Serta Penerapannya Dengan Model Pembelajaran Kooperatif". Tesis tidak diterbitkan. Surabaya: Pascasarjana UNESA.

[17] Mario, Conny. 2004. "Penerapan Strategi Belajar PQ4R Pada Materi Pokok Komponen Ekosistem Peran dan Interaksinya Dalam Upaya Menuntaskan Hasil Belajar". Tesis tidak diterbitkan. Surabaya: Pascasarjana UNESA.

[18] Matius, Benyamin. 2009. "Pengembangan Perangkat Pembelajaran Pada Pelajaran Sains Kelas V SD Kajian Peristiwa Alam dan Sumber Daya Alam Dengan Menerapkan Model Pembelajaran Kooperatif Tipe STAD”. Tesis tidak diterbitkan. Surabaya: Pascasarjana UNESA.

[19] Martinus, Yasmin. 2006. Strategi Pembelajaran Berbasis Kompetensi. Jakarta: Gaung Persada Press.

[20] Maswiyanto. 2012. "Pengembangan Perangkat Model Pembelajaran Kooperatif Tipe NHT Dalam Pengembangan Kimia Materi Koloid”. Tesis tidak diterbitkan. Surabaya: Pascasarjana UNESA.

[21] Mulyasa, E. 2007. Perencanaan Pembelajaran ; Mengembangkan Standar Kompetensi Guru. Bandung: Rosdakarya. 
[22] Nur, Muhammad. Prof. Dr. 2011. Model Pembelajaran Berdasarkan Masalah. Surabaya: PSMS.

[23] Nur, Muhammad. Prof. Dr. \& Dra. Prima Wikandari, M.Si. 2008. Pengajaran Berpusat Kepada Siswa dan Pendekatan Konstruktivis Dalam Pembelajaran. Surabaya: PSMS

[24] Nur, Muhammad. Prof. Dr., Dra. Prima Retno Wikandari, M.Si., \& Drs. Bambang Sugiato, M.Pd. Teori-Teori Pembelajaran Konitif. Surabaya: PSMS

[25] Purwanto, Tyas Ari. 2012. "Pengembangan Modul Berbasis Strategi Metakognitif pada Mata Pelajaran Mengolah Makanan Indonesia di SMK N 2 Tuban". Skripsi tidak diterbitkan. Surabaya : FT UNESA.

[26] Rohman. Faisol. 2008. Meningkatkan Kreativitas. (http://faisalrohman.blogspot.com/2008/04/judul-skripsimeningkatkan-kreativitas.html tanggal 06 Agustus 2012)

[27] Rooijakkers. Ad. 1991. Mengajar Dengan Sukses. Jakarta : PT Grasindo.

[28] Roziqin, Anang A. 2008. "Pengembangan Media Pembelajaran Berbasis Macromedia Flash 8 Pada Materi Membubut Di SMK Teknik Permesinan". Skripsi tidak diterbitkan. Surabaya : FT UNESA.

[29] Sadirman. 2007. Interaksi dan Motivasi Belajar Mengajar. Jakarta: PT. Raja Grafindo Persada.

[30] Samo, Daimanus. 2011. "Kreativitas Siswa Dalam Memecahkan Masalah Matematika Ditinjau Dari Kemampuan Matematika Siswa". Tesis tidak diterbitkan. Surabaya: Pascasarjana UNESA.

[31] Semiawan, Conny. R. 2010. Kreativitas Keberkatan: Mengapa, Apa dan Bagaimana. Jakarta: PT. Indeks/

[32] Slameto. 1988. Evaluasi Pendidikan. Jakarta: Bina Kasara.

[33] Slameto. 1995. Belajar dan Faktor Yang Mempengaruhinya. Jakarta : Rineka Cipta.
[34] Suaidin. 2010. Teknk Penyusunan Modul (Online). (http://suaidinmath.wordpress.com/2010/05/09/teknik-penyusunanmodul/ tanggal 02/05/2012)

[35] Sudarman, 2000. Problem Based Learning : Suatu Model Pembelajara untuk Mengembangkan dan Meningkatkan Kemampuan Memecahkan Masalah (Online).
. (http://physicsmaster.orgfree.com/Artikel\%20\&\%20Jurnal/Wawasan\% 20Pendidikan/PBL\%20Model.pdf tanggal 02/07/2012)

[36] Sudjana. Prof. DR. M.A., M.Sc. 2005. Metode Statistik. Bandung: PT. Tarsito.

[37] Sugiyono. Prof. DR. 2011. Statistic Untuk Penelitian. Bandung: CV. ALfabeta.

[38] Tim Fakultas Teknik Universitas Negeri Surabaya. 2001. Merawat Tangan, Kaki Dan Rias Kuku. Jakarta: Departemen Pendidikan Nasional

[39] Tim. 2008. Bse Tata Kecantikan Kulit Jilid 2. Jakarta : Direktorat Pembinaan Sekolah Menengah Kejuruan.

[40] Toselli, Leigh. 2008. Panduan Lengkap Manikur dan Pedikur. Jakarta : Gramedia Pustaka Utama.

[41] Utami, Ratna Yustika. 2011. "Pengembangan Buku Ajar Biologi Berorientasi Contextual Teaching Learning (CTL) Pada Materi Sistem Pencernaan Manusia di Kelas VIII SMP”. Skripsi tidak diterbitkan. Surabaya : FMIPA UNESA.

[42] Wikipedia. 2010. Studi Kelayakan (Online). (http://id.wikipedia.org/wiki/Wikipedia:Studi kelayakan tanggal 01 Maret 2013)

[43] Wijayanti, Dian Ayu. 2012. "Pengembangan Model Pembelajaran Berdasarkan Masalah Pada Kompetensi Perawatan Rambut Secara Basah (Creambath) Untuk Mengetahui Hasil Belajar Siswa Pada Kelas X SMK Negeri 2 Lumajang”. Skripsi tidak diterbitkan. Surabaya : FT UNESA. 